УДК 81’25 (045)

\title{
ПОМИЛКИ В АУДІОВІЗУАЛЬНОМУ ПЕРЕКЛАДІ: ЛІНГВІСТИЧНИЙ І ДИДАКТИЧНИЙ АСПЕКТИ
}

\author{
ТЕРЕЩЕНКО Л. Я. \\ кандидат філологічних наук \\ Вінницький торговельно-економічний інститут \\ Київського національного торговельно-економічного університету \\ tereshchenko_1@yahoo.com
}

\begin{abstract}
У статті проаналізовано типові помилки, що стаються при перекладі аудіовізуальних текстів. Матеріалом дослідження послугували випадки невдалого закадрового перекладу англомовних художніх та документальних серіалів, перекладених українською та російською мовами. 3'ясовано лінгвальні та екстралінгвальні фактори, які, імовірно, впливали на вибір перекладача й зумовили виникнення помилок, зокрема: ігнорування історико-культурного контексту, стилістична і тематична нерелевантність, викривлення лексико-синтаксичних особливостей вихідного тексту тощо. Доведено необхідність застосування подібного аналізу в навчанні майбутніх перекладачів 3 метою надання їм адекватних інструментів подолання проблемних ситуацій під час перекладу фільмів іноземного виробництва.

Ключові слова: аудіовізуальний переклад, закадровий переклад, перекладацькі помилки, кінотекст.

\section{MISTAKES IN AUDIOVISUAL TRANSLATION: LINGUISTIC AND DIDACTIC ASPECTS}

TERESHCHENKO Liliia Yakivna Candidate of Scinces (Philology), Assistant Professor Vinnytsia Trade and Economy Institute Kyiv National Trade and Economy University tereshchenko_1@yahoo.com
\end{abstract}

Introduction: Mistakes in audiovisual translation are generally caused by a wide range of lingual and extralingual factors. Translators' unawareness of the nature of these factors hampers the process of translation and results in misinterpretation of the message by the addressee. With fansubbing and crowdsourcing spreading worldwide, more and more experts are becoming concerned with poor quality translations sprouting up before or simultaneously with the professionally interpreted or dubbed versions. Ukraine seems to have finally overcome the hardly comprehensible voiceover of pirate DVDs (a sad legacy of the early 1990s). However, Ukrainian audience is still struggling to understand some of the 'quick fix' versions of TV series, which appear to be too numerous to be properly translated.

Purpose: The objective of the article is to analyze typical mistakes that can occur in audiovisual translation and to outline the major causes of these mistakes.

Methods: The research is based on randomly selected cases of inadequate voiceover translation of English fiction and documentary series into Ukrainian and Russian. The choice of the films was prompted by the commentaries of Internet-users who indicated insufficient quality of translation of these films. Mistakes found were then analyzed from the point of view of language and culture-specific constraints, interpreting mode constraints and personal constraints that might have affected the translator's choice.

Results: Apart from widely known linguistic phenomena of polysemy, homonymy, lexical lacunas, there are other stumbling blocks to faithful translation, such as lack of attention to historical and cultural context, inappropriate stylistic toning, thematic irrelevance, and even 
Терещенко Л. Я. Помилки в аудіовізуальному перекладі: лінгвістичний і дидактичний аспекти

blunt incoherence of verbal and visual features, etc. Due to the multimode nature of audiovisual translations some of the problems could easily be solved if translators actually watched the film, instead of hastily working on the script.

Conclusions: Similar analysis of translators' mistakes is suggested as a means of teaching novice translators to develop efficient tools of overcoming difficult cases while translating foreign films.

Keywords: audiovisual translation, voice-over, translators' mistakes, film text.

Формулювання проблеми та обгрунтування актуальності їі розв'язання. Думка про те, що переклад - нелегка справа, а особливо аудіовізуальний переклад, що вимагає не лише глибокого знання двох мов, а й особливої майстерності, $є$ на стільки ж буденною, наскільки й правдивою. Утім новий час ставить перекладачів перед новими викликами: англійські неологізми рясніють на шпальтах газет, у соціальних мережах та в мовленні персонажів художніх фільмів, як то to defriend / unfriend someone on Facebook, “momager" (a celebrity's business manager who is actually their mother), webisode (an episode or series created exclusively for online viewing), binge-watch (watch multiple episodes of a TV show, one after another, in a single sitting).Часом здається, що тисячі людей одночасно зрозуміли правила мовної гри і отримують величезне задоволення від неї. Очевидним відгуком перекладачів на подібні зміни є постійне самовдосконалення, моніторинг сучасних засобів інформації та електронних засобів комунікації, відстеження сучасних лексикологічних, соціолінгвістичних досліджень, про що пишуть вітчизняні дослідники (Кравець, Таценко, 2012; Мельник, 2012; Coфiєнко, 2014; Chugu, Gladio, 2015). Окрім такого загального спрямування на підвищення своєї професійної майстерності, перекладачі, однак, потребують аналітичних інструментів, що допоможуть їм визначити проблемні моменти, конкретизувати суть проблеми, виявити джерела її вирішення i, зрештою, власне розв'язати проблему.

Мета статті - проаналізувати типові проблеми, що виникають у перекладачів англомовних фільмів українською і російською мовами, та виявити можливі причини виникнення труднощів при перекладі закордонних фільмів.

Об'єктом нашого дослідження послуговували закадрові переклади (voice-over) англомовних художніх та документальних телесеріалів “Bones”, “Еpic History of Everyday Things", "Hercule Poirot”, “Call the Midwife”, виконані різними студіями звукозапису. Назви студій та імена перекладачів не згадуємо з етичних міркувань. Відбір серіалів ми проводили з урахуванням думки глядачів, котрі висловлювали своє незадоволення якістю перекладу на відповідних кіносайтах у мережі Internet, тобто недоліки перекладу об'єктивно встановили не лише фахівціексперти, а й пересічні глядачі.

Аналіз останніх досліджень і публікацій. Увага до аудіовізуального перекладу зростає пропорційно до тієї кількості кінопродукції та розважального (ігрового) програмного забезпечення, котрі виходять на світовий ринок. Наразі відомі спроби не лише класифікувати підвиди аудіовізуального перекладу, але й визначити поширеність цих типів у різних країнах та серед різних груп глядачів, зокрема ведеться дискусія про переваги й недоліки субтитрування і дублювання фільмів (Ayonghe, Ategha, 2017; Bartolomé, Carbera, 2005). Frederic Chaume (2013) виокремлює такі види аудіовізуального перекладу: дублювання (dubbing), субтитри (subtitling), титри з текстами пісень або лібрето (surtitling), сурдопереклад (subtitling for the deaf), субтитри в режимі реального часу (respeaking), поєднання дубляжу і субтитрів (audiosubtitling), закадровий переклад (voice-over), синхронний переклад фільмів на кінофестивалях (simultaneous interpreting at film festivals), вільний коментар (free-commentary), аудіоопис для людей, котрі не можуть бачити візуальний контент (audiodescription), пародійний переклад (goblin translation), аматорські дубляж і субтитри (fansubbing and fandubbing). При цьому дослідник відзначає, що різні соціальновікові групи формують різне ставлення до окремих підвидів аудіовізуального перекладу. 
Yves Gambier (2016) пропонує поділяти перераховані вище види аудіовізуального перекладу на дві категорії: переклад (можливо, доречніше було б ужити термін “інтерпретація") у межах однієї мови, що охоплює чотири види, та міжмовний переклад (8 видів). Звичайно, кожен підтип має свої особливості, котрі неможливо відстежити в межах однієї статті. Ми зосередили свою увагу лише на випадках закадрового перекладу, який $є$ найбільш поширеним в Україні через відносно низьку собівартість процесу виробництва.

Оскільки обсяг аудіовізуальної продукції зростає щорічно в геометричній прогресії, далеко не всі продукти потрапляють до рук професіоналів. Поширення аматорського дубляжу й субтитрів призвело до того, що в деяких країнах, насамперед у Китаї, Японії, Південній Кореї, перед релізом офіційно перекладеної версії фільму з'являються кілька аматорських варіантів, якість яких дуже різниться, але здебільшого є надзвичайно низькою (Cintas, Sánchez, 2006; Wang, 2017). Це пов'язане з особливостями формату, що перекладається (без монтажних листів часто іде запис "на слух"), і з професійним рівнем самих перекладачів. До таких сумнівних продуктів відносять і результат “краудсорсингу” (crowdsourcing), коли переклад здійснюється кількома волонтерами, котрі можуть взагалі не мати професійної освіти чи досвіду (Gambier, 2016, с. 893).

Звичайно, зі зростанням функціоналу штучних нейронних мереж, задіяних з 2016 року в перекладацьких програмах компаній Google i Microsoft (Wu, Schuster, Chen, Le, Norouzi, 2016), та з розвитком технічних засобів здійснення аудіовізуального перекладу, зокрема програмного забезпечення для створення субтитрів (Cintas, 2008), можемо прогнозувати розвиток $з$ плином часу нового підтипу аудіовізуального перекладу - машинного аудіовізуального перекладу.

На щастя, на теренах України нерозбірливий, одноголосий переклад піратських DVD кінця XX століття, здається, уже відійшов у минуле. В Україні поступово формується власна школа кіноперекладу, яка ідеологічно й методично відходить від радянських традицій (Софієнко, 2014). Однак сучасні глядачі висувають значно вищі вимоги до перекладу, адже здатні й самі помітити недоліки та помилки в дубльованому фільмі, що доводить у своєму дослідженні A. Artiukh (2015), а також активно висловлюють свої зауваження на відповідних сайтах.

Отож назріла реальна потреба фахової підготовки фахівців аудіовізуального перекладу, про що заявляють автори монографіï The Didactics of Audiovisual Translation (Cintas, 2008, с. 3 - 4]. Дослідники погоджуються, що підготовка фахівця з аудіовізуального перекладу вимагає не лише розробки теоретичного підгрунтя такої діяльності та поглиблення відповідних знань новачків, але й насамперед систематичного тренування, що супроводжується докладним аналізом вдалих і невдалих зразків (Cintas, 2008; Xiangdong, 2015). Цікавим і корисним поєднанням теорії та практики $\epsilon$, на нашу думку, обговорення саме невдалих випадків перекладу, адже в ході аналізу розкриваються глибинні процеси інтерпретації та мотиви перекладача щодо вибору певних засобів мовного вираження змісту художнього чи документального фільму.

У своїй статті А. Артюх (Artiukh, 2015) пропонує таку класифікацію причин перекладацьких помилок: 1) непрофесіоналізм, 2) нездатність розпізнати культурно-специфічну лексику, 3) “хибні друзі перекладача", 4) буквальний переклад, 5) різновиди омонімії, 6) синонімія, 7) паронімія. Хоча в іiі роботі було наведено безумовно цікавий та яскравий ілюстративний матеріал, ми вважаємо можливим запропонувати свою класифікацію причин перекладацьких помилок, оскільки авторка не окреслила критерії виокремлення наведених нею типів, котрі $\epsilon$ дуже різними за своєї природою.

Виклад основного матеріалу дослідження. Цілком очевидно, що частина проблемних ситуацій може бути спричинена властивостями самого аудіовізуального тексту, тоді як інші $\epsilon$ типовими “каменями спотикання" будь-якого перекладу (див. табл. 1). Порівнюючи різні формати текстів для перекладу, Patrick Zabalbeascoa (2008, с. 21) вказує, що аудіовізуальний текст, як комунікативний акт, охоплює звук і образи, є мультимодальним за своєю природою, а відтак містить додаткові перепони для перекладу, ніж простий усний чи письмовий текст. 
Зокрема, надзвичайно важливим є відношення між відеорядом і озвученим текстом. Ми відносимо до проблемних моментів аудіовізуального перекладу також процес локалізації та проблеми, що виникають через формат збереження перекладу.

Типовими перепонами для перекладу взагалі і перекладу фільмів зокрема є різноманітні лінгвальні чинники (полісемія та омонімія, тема-рематичне членування, гра слів, відсутність синтаксичних конструкцій у мові перекладу тощо) та екстралінгвальні чинники, серед яких, на нашу думку, визначальний вплив на якість перекладу фільму мають персональні характеристики перекладача та культурно-історичні чинники. Розглянемо нижче реальні приклади різних типів проблемних ситуацій.

Табл. 1

Типи проблем в аудіовізуальному перекладі

\begin{tabular}{|c|c|}
\hline $\begin{array}{c}\text { Проблемні моменти, притаманні } \\
\text { аудіовізуальному перекладу }\end{array}$ & $\begin{array}{c}\text { Проблеми, що притаманні будь-якому типу } \\
\text { перекладу, включаючи аудіовізуальний }\end{array}$ \\
\hline 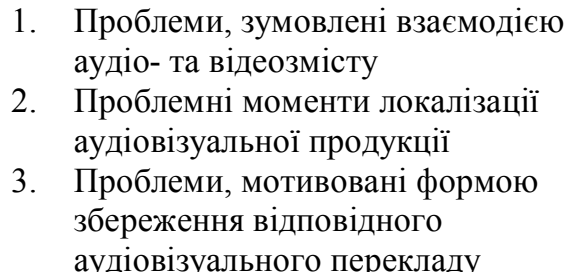 & $\begin{array}{l}\text { 1. Проблеми, спричинені лінгвальними } \\
\text { чинниками } \\
\text { 2. Проблеми, пов'язані з екстралінгвальними } \\
\text { чинниками: } \\
\text { 1) особистісні характеристики перекладача } \\
\text { 2) історико-культурні чинники }\end{array}$ \\
\hline
\end{tabular}

Труднощі, 3 якими стикаються перекладачі кінопродукції, викликані складною семантикою аудіовізуального тексту, який є креолізованим та прецедентним. У. Еко вважав, що зміст кінотексту передається трьома видами кодів: портретним (іконічним), звуковим та лінгвальним. Однак російські учені Г.Г. Слишкін та М.А. Єфремова (2004) зауважують, що протиставлення звукового та лінгвального кодів є необ'єктивним, оскільки усне мовлення теж має звукову природу. Дослідники пропонують виокремлювати дві антиномії: протиставлення аудіо та візуальних семіотичних компонентів та протиставлення лінгвальних і нелінгвальних компонентів кінотексту (Слышкин, Ефремова, 2004, с. 20-21). Зрештою, Yves Gambier (2016) вдалося об'єднати ці ідеї, виокремивши лінгвальний зміст, виражений аудіо та відео засобами, та нелінгвальний зміст, також виражений аудіо- та відеозасобами. Відношення між цими видами змісту можуть бути спрямовані не лише на спільність думки, взаємодоповнення, але й існувати у форматі надлишковості чи протиставлення (Cintas, 2008). Однак інколи протиставлення відеоряду та тексту є ненавмисним, зумовленим хибним перекладом.

Згадаємо, наприклад, досить відомий британський серіал “Sherlock”. В одному з епізодів головний герой купує на вулиці традиційну британську страву fish and chips (смажену картоплю 3 рибою), яку перекладач російськомовної версії плутає 3 американською лексемою chips і перекладає як “чіпси”. При цьому на екрані абсолютно чітко видно, що саме їсть головний герой. Очевидно, цієї помилки можна було б уникнути, якби перекладачі уважно переглядали фільм перед тим, як працювати з текстом, а варіанти перекладу, котрі спадають на думку, але викликають когнітивний дисонанс, дивують протиставленням лінгвального та нелінгвального планів, перевіряли б з додатковою ретельністю, адже більшість 3 них виявляються так званими “хибними друзями перекладача".

Аналогічною за причинами та ефектом є ситуація, коли в епізоді серіалу “Call the Midwife” героїні стає зле, вона хапається за серце, а далі ми бачимо їі в лікарні та чуємо переклад телефонної розмови, у якій вона повідомляє, що в неї ангіна і тому доведеться відкласти заплановану поїздку на місяць. Навіть для недосвідчених глядачів є очевидним помилковий переклад слова angina, котре позначає “стенокардію”, а не лише “ангіну”, як було перекладено. 
Крім протиставлення лінгвального та нелінгвального планів, в аудіовізуальному перекладі трапляються випадки, коли не збігаються усний і письмовий текст, одночасно представлені глядачеві. Це зумовлено тим, що є обмеження як для субтитрів (письмовий текст на екрані не може бути довшим за два рядки, щоб його встигли прочитати), так і для усного перекладу, який потрібно синхронізувати з довжиною оригінального усного тексту.

У документальному серіалі “Еріс History of Everyday Things” ситуація ускладнилася тим, що інформативні написи на екрані не мають субтитрів. Частина цих написів озвучується диктором, котрому й без того потрібно пришвидшити свій темп, щоб зачитати український переклад, який зазвичай довший, ніж англійський оригінал. Більшість написів залишилася неперекладеною взагалі. У якийсь момент глядач, котрий слухає про походження консервованих продуктів, може прочитати на екрані напис “....SPAM introduced”. У більшості аудіовізуальних перекладів подібні написи локалізуються, тобто перекладаються та розташовуються в тих самих місцях, що й в оригіналі, як це було зроблено, наприклад, у серіалі “Sherlock". Цей момент можна було б оминути, якби напис “....SPAM introduced” не був представлений великим літерами й акронім не нагадував знайоме усім сучасним Інтернет-користувачам слово “спам”. Залишена без пояснення назва м'ясного продукту торгової марки Hormel Foods Corporation викликає спантеличення в глядачів, чиї асоціації не допомагають їм зрозуміти зв'язок між текстом на екрані та усним текстом, що його супроводжує.

Відмова від субтитрів у цьому серіалі призвела до того, що напис на екрані “Humans are the only animals who bury their dead” був усно перекладений як “Люди-тварини, які закопують мертвих”, котрий, імовірно, виник через прагнення “втиснути” мовлення диктора в ті кілька секунд, поки напис був на екрані. Однак очевидно, що англійська та українська версії мають суттєві логічні розбіжності.

3 огляду на складність семантичного переносу, ми погоджуємось із зауваженням Yves Gambier (2016) про те, що оцінювати якість аудіовізуального перекладу потрібно не лише 3 погляду зрозумілості тексту, а й з огляду на його прийнятність, доступність та зручність для глядачів. Така прагматична спрямованість на адресата виявляється в сучасних фільмах у формі локалізації, коли деякі риси оригінального аудіовізуального продукту адаптуються до конкретної аудиторії у лінгвальному і культурному плані, аби він не відчувався як чужорідний продукт (Gambier, 2016, с. 892). Вдалим прикладом локалізації ми вважаємо український переклад мовлення одного з персонажів анімаційного фільму “Таємне життя домашніх тварин” (2016) за допомогою діалектного мовлення, котре втілює харизматичність цього персонажа і створює комічний ефект.

Українському глядачеві незвично чути, що хтось випив 1500 мл рідини, а не півтора літра (серіал “Bones”), і ще більше незрозуміло, скільки сиру з'їдає щороку пересічний американець, якщо звучить цифра 32 фунти, також досить важко уявити 4-дюймові підбори короля Луї XIV (“Epic History of Everyday Things”). Подібні випадки найкраще переводити у знайому аудиторії метричну систему.

3 іншого боку, локалізація не повинна спотворювати змісту оригінального продукту. D. Wang (2017) наводить яскраві приклади того, як перекладачі занадто сильно змінюють лексико-семантичне наповнення тексту. Наприклад, у китайському перекладі опис потворної істоти 'That is one ugly, mug-ugly lady!' (анімаційний фільм “Madagascar 3”) перетворився на досить поетичний, але стилістично дуже далекий переклад, котрий українською приблизно звучав би як “Ця жінка така потворна, щзо вона вразила б і Небеса, і Землю та змусила б богів i духів плакати” (переклад цього та наступного фрагменту здійснено нами українською 3 підрядкового перекладу китайської на англійську, представленого D. Wang (2017, с. 184). Ще один фрагмент того ж анімаційного фільму в іншому китайському перекладі був настільки локалізований, що стає абсолютно незрозумілим для глядачів з інших країн. Вислів 'Cause 
all you have to do is put them around your partner' ("Все, що треба, - просто обійняти партнера [по танцю]") перекладено приблизно так: "Ми попрацюємо як подружжя, точнісінько як Шеньян у Зірковому Авеню”. Для китайської аудиторії, котра пам’ятає про перемогу цього коміка в китайському шоу талантів у 2009 році, можливо, переклад і не звучить безглуздо, однак він дуже далекий від реального вислову і $є$ невиправдано перевантаженим, оскільки містить момент інтертекстуальності.

Проблеми аудіовізуального перекладу можуть бути пов'язані з різноманіттям форм збереження відповідного аудіовізуального перекладу. Наприклад, якщо говорити про можливості вибору мови перегляду фільму на DVD, здебільшого він досить обмежений. Не завжди доступна функція відкритих субтитрів, щоб їх можна було вмикати і вимикати за потребою i на різних мовах. Усе більшого поширення набувають субтитри в режимі реального часу, котрі через брак часу для перекладу можуть містити помилки (Zabalbeascoa, 2008, с. 35-36). Можливість “перезаливання" перекладу на файлообмінних сайтах привела до того, що один і той же фільм можна подивитись у різних перекладах, що $є$ позитивним моментом, якщо говорити про конкуренцію між різними студіями звукозапису, але й $\epsilon$ негативним з погляду того, що виникає проблема авторства і відповідальності, адже деякі зловмисники навмисно подають спотворений переклад, часто з інвективною лексикою, навіть для дитячої продукції.

Проблеми перекладу, зокрема й аудіовізуального, можуть бути спричинені двома видами чинників - лінгвальними й екстралінгвальними. Лінгвальні перешкоди для якісного перекладу досліджені найкраще, адже саме лінгвісти найбільше досліджували теоретичні та практичні аспекти перекладу. Серед мовних проблем перекладу найпоширеніші, за нашим спостереженням, такі:

1. Нехтування стилістичним компонентом.

У сучасному детективному серіалі, наприклад, нетипово старомодно звучить зізнання “ $V$ меня был адюльтер" (серіал “Bones"), яке містить буквальний відповідник слова adultery і може бути замінене простішим "У меня был роман".

Ще дивніше звучить діалог у тому ж серіалі між жінкою-детективом та матір'ю, котра втратила дитину і вказує на те, що детектив не здатна зрозуміти ії почуття. Замість стишеної тональності, котра підтримує відчуття згорьованості, глядачі чують: "Вы не мать". "Нет, я не мать”. Доречніше було б, на нашу думку, обрати нейтральні, хоч і стереотипні фрази, на зразок: “У вас нет своих детей”. "Нет”. Тоді текст не викликав би змішаних почуттів.

В описі “Усі чоловіки: лідери міст, політики, солдати...” (“Epic History of Everyday Things"), лексема лідер (буквальний відповідник слова leaders) вжита всупереч контексту, адже, по-перше, не враховано лексичної валентності цього слова, по-друге, лідерами в українській мові здебільшого називають людей, котрі очолюють суспільно-політичні організації, або тих, хто показує найкращі результати в певних змаганнях (СУМ). Вираз leaders of the cities пропонуємо перекладати як “керівники” або "очільники міст".

Узагалі можна сказати, що багато кіноперекладів потерпають саме від буквалізму, котрого можна було б уникнути за допомогою елементарних семантичних та граматичних трансформацій. "One today, one tomorrow," - каже герой серіалу “Bones". "Одна сегодня, одна - завтра," дзеркально повторює на ним перекладач, хоча природніше звучить вираз "Сегодня - одна, завтра - другая."

2. Плутанина темо-рематичних елементів.

Твердження про те, що “периий ресторан відкрився у Бостоні у 1794 роиіі", викривлює не лише історичні події, але й зміст висловлення "In 1794, the first US restaurant opened in Boston", яке прозвучало в англомовній версії документального серіалу. Намагаючись зберегти порядок теми і реми, перекладач потрапив у пастку, адже у такому випадку не залишилося місця для перекладу лексеми US: або виникає хибне тлумачення “американського ресторану" 
як ресторану американської кухні, або послідовно будуть іти дві синтаксично паралельні конструкції “перший ресторан у США відкрився у Бостоні”. Так чи інакше, перекладач фільму уникнув громіздкості та неясності висловлення, просто оминувши лексему US у тексті, змінивши при цьому і фрагмент світової історії, адже в наявному перекладі виникає імпліцитний натяк на перший ресторан у світі. Вважаємо, що ситуацію міг би врятувати такий переклад: "У 1794 році в Бостоні відкрився перший ресторан у Сполучених Штатах".

3. Невдалий вибір значення у випадку полісемії.

Переклад речення As a toothbrush Egyptians used twigs ("Epic History of Everyday Things") Роль щітки виконувала лоза - містить лексему “лоза”, котра хоч і може бути варіантом перекладу лексеми twig, все ж позначає стебло деяких кущових рослин (СУМ) (особливо верби, котра навряд чи росла в Давньому Єгипті), тоді як слово twig позначає будь-яку тоненьку гілочку. Загалом наведений переклад викликає недоречні асоціації з вербами та лозами.

У перекладеній версії детективного серіалу “Bones” чуємо таку розмову:

- Вы убили.

- Я с этим не согласен.

Хоч вираз I deny it поза контекстом міг би мати подібне значення, у цьому випадку вважаємо доречнішим вираз “Я это отрицаю” (“Я це заперечую”).

Аналогічно, речення "Until the 1700's forks were thought unmanly", перекладене як “До вісімнадиятого століття виделки вважалися жіночними”, можливо, і містить правильний словниковий відповідник лексеми unmanly, але він не відображає адекватно зміст тексту, у якому йдеться про те, що виделки вважались не гідними чоловіка, тобто користування виделками не було чоловічою справою.

Досить поширеною $€$ помилка при перекладі виразів з лексемою find, котра окрім значення “знаходити” вживається ще й у значеннях “виявити”, “опинитись”, “дізнатись”, наприклад: висловлення "Я нахожу (I find), что в этом деле я не могу быть объективной” природніше звучатиме у варіанті “Я обнаружила" / "Я вижу".

"Знаешь, почему твоя фамилия Свитс? Потому что ты мильй” У цьому випадку гра слів, зав'язана на прізвищі персонажа, очевидно, не може бути збережена, оскільки прізвище не перекладається. Однак саме питання “Знаешь, почему твоя фамилия Свитс?” (Do you know why you are called Sweets?) звучить досить безглуздо, адже кожна людина абсолютно точно знає, чому вона має своє прізвище. Річ у тім, що персонажа, котрий був надзвичайно доброзичливим, yсі друзі і колеги називали лише Sweets, перетворивши прізвище на прізвисько. Таким чином, ближчою до оригіналу була б версія “Ты такой милый. Не зря все называют тебя Свитс.”

Переклад речення "The demand for food flavourings sent explorers to the far ends of the Earth" формі “Зростаючі вимоги щодо ӥжі відправляли дослідників на Далекий Схід” викликає зауваження щодо варіанта “вимоги” (краще було б “"опит”) та пропуску вважливого лексичного компонента flavourings (“прянощі"), без якого експансія європейців на Далекий Схід здається зумовленою нестачею їжі. Вище ми згадували вже, що причиною перекладацьких помилок стають також явища омонімії, паронімії та "хибних друзів перекладача".

Повертаючись до екстралінгвальних чинників, що стоять на заваді якісному перекладу, наведемо кілька прикладів того, як перекладач викривлює текст з особистих причин. По-перше, перекладач може не усвідомлювати, що його переклад не $є$ тематично релевантним. Наприклад, звернення чоловіка до померлої дружини на кладовищі “Ты отдохнешь, Айрис, я обешаю”" (You will find peace, I promise you, Iris) звучить, м'яко кажучи, дивно (серіал “Hercule Poirot”). Пропонуємо свій варіант: “Твоя душа обретет покой, Айрис, я обещаю.”

Перекладачеві, котрий не переймається перипетіями сюжетної лінії, не здається дивним те, що чоловік, звертаючись до своєї колеги, з якою у нього немає і ще протягом 1-2 сезонів не буде романтичного зв’язку, каже “Это моя девушка!”(серіал “Вones”). Насправді герой фільму лише схвально оцінив роботу своєї напарниці: That's my girl! (“Молодчина!"). 
Низький професійний рівень перекладача, брак знань та слабка інтуїція стають великою завадою для перекладу сучасних фільмів, наповнених новими фразеологізмами. Опис нового хлопця головної героїні, перекладений у такий спосіб: “Он хитрее, чем мартышика со щенком" (серіал "Bones”), є яскравим прикладом такої непрофесійної роботи. Вираз "as cheeky as a monkey with a puppy" можна було б перекласти так: “А он проказник еще тот!”

У різні часи перекладачі володіли різною інформацією про історико-культурні та соціальні реалії інших країн. Однак сьогодні доступ до інформації майже безмежний, тому професійний перекладач зобов' язаний ураховувати етикетні формули, особливості адміністративної, судової, освітньої систем, традицій та обрядовість країн, у яких відбуваються події фільму. Наведемо кілька прикладів, коли ці моменти були проігноровані:

a) "It was a pleasure"

"С удовольствием, Мел" (Насправді мало б бути "Приятно было познакомиться" етикетна формула при першому знайомстві).

б) "На нее, наверное, давит глава графства" (Насправді “головний інспектор округу" (“chief county inspector”, оскільки у США немає адміністративного поділу на графства).

в) High school - "высшая школа" (у США це старша, а не вища школа).

г) Jury - “жюри присяжных” ( потрібно: “суд присяжних”).

г) “Оденьте что-нибудь синее и не носите увесистое ожерелье” (Оскільки в оригіналі згадано сині панчохи - "blue stocking” - вираз, відомий і англійському, і російському, й українському глядачеві, доречніше було б зберегти його, аби донести підтекст висловлювання, наприклад: "Оденьте что-нибудь синее, главное не чулки и не бабушкино ожерелье").

д) "Нет, я не хочу портить тебе Рождество. Приезжай в День бокса." (Насправді герой мав на увазі День подарунків (Boxing Day), який відзначають 26 грудня).

Висновки й перспективи подальших досліджень. Уникненню проаналізованих у статті помилок посприяє постійне професійне самовдосконалення перекладачів, поглиблення їхніх фонових знань про культуру, історію та устрій інших країн, ознайомлення з різновидами соціолектів та діалектів, уважне ставлення до порівняльних аспектів граматики та лексики тощо. Важливою запорукою вдалих перекладів $є$ електронна грамотність перекладачів уміння користуватися різноманітними електронними джерелами, котрі допоможуть з'ясувати культурологічні питання, перевірити лексичну й граматичну валентність слів, уточнити значення нових лексичних одиниць тощо. Проведене нами пілотне опитування студентів філологічного та нефілологічного профілю показало, що філологи користуються в середньому трьома електронними засобами перекладу, а студенти інших спеціальностей - одним, що $є$ дуже обмеженим в обох випадках. Отже, наразі можемо констатувати потребу в навчанні перекладачів передових технологій на матеріалі, котрий би відтворював реальні проблемні ситуації, які доведеться розв'язувати майбутнім фахівцям.

Дидактичний потенціал подібних досліджень полягає в тому, що вони можуть стати основою для створення бази даних помилок аудіовізуального перекладу та допомогти в розробці необхідного програмного забезпечення, котре дозволило б здобувачам відповідного фаху тренуватися на подібних зразках, виявляти проблемні місця в кінофрагментах, аналізувати чинники, що спричинили ці помилки, пропонувати власні способи подолання цих проблемних місць і порівнювати власні варіанти перекладу зі зразком.

Перспективи подальших досліджень полягають у вивченні реакції аудиторії на перекладацькі помилки, встановлення відсотка помилок, котрі здатні помітити нефахівці, та дослідженні впливу перекладацьких помилок на загальне і глибоке розуміння глядачами змісту перекладеного аудіовізуального тексту. 


\section{ЛIТЕРАТУРА}

Кравець, Л. С. і Таценко, Н. В. (2012). Соціокультурні аспекти перекладу серіалів з англійської мови на українську. Філологічні трактати. 4 (3), 45-49.

Мельник, А. П. (2012). Український колорит у перекладах сучасних анімаційних фільмів. Мовні і кониептуальні картини світу. 42 (1), 103-113.

Софієнко, І. В. (2014). Становлення кіноперекладу в Україні. Мовні і конщептуальні картини свіmy. 50(2), 401-405. Взято 3 http://nbuv.gov.ua/UJRN/Mikks_2014_50\%282\%29_59 .

Слышкин, Г. Г. И Ефремова, М. А. (2004). Кинотекст (опьтт лингвокультурологического анализа). Москва: Водолей Publishers.

Artiukh, A. O. (2015). Classification of translators' mistakes in the movies for the Ukrainian audience. Вісник Національного технічного університету Украӥни "Киӥвський політехнічний інститут". Серія: Філологія. Педагогіка. 5, 9-15. Взято 3 http://nbuv.gov.ua/UJRN/vntufil_2015_5_4.

Ayonghe, L. S. \& Ategha, A. (2017). The Power of film translation: Cameroon film industry and television documentaries: dubbing or subtitling? Translation Journal. January Issue. Retrieved from http://translationjournal.net/January-2017/the-power-of-film-translation-cameroon-film-industryand-television-documentaries-dubbing-or-subtitling.html .

Bartolomé, A. I. H. \& Carbera, G. M. (2005). New trends in audiovisual translation: the latest challenging modes. Miscélanea : A Journal of English and American studies. 31, 89-104.

Chaume, F. (2013). The turn of audiovisual translation: new audiences and new technologies. Translation spaces. 2 (1), 105-123.

Chugu, S. \& Gladio, S. (2015). Modality of the literary text: Translation challenges. Наукові записки Національного університету “Острозька академія". Серія "Філологічна". 59, 6-8.

Cintas, J. D. \& Sánchez, P. M. (2006). Fansubs: Audiovisual translation in an amateur environment. The Journal of Specialized translation. 06, 37-52. Retrieved from http://www.jostrans.org/ issue06/art_diaz_munoz.php .

Cintas, J. D. (2008) Introduction. The Didactics of Audiovisual Translation. John Benjamins Publishing Company, (pp. 1-18).

Gambier, Y. (2016). Rapid and radical changes in translation and translation studies. International Journal of Communication. 10, 887-906.

Tarquini, G. (2016). The deployment of audiovisual databases in foreign language learning: usability features and didactic affordances. Verstehen durch Hören und Lesen. Teil II: Perspektiven interlingualer Untertitelung 9:2, 208-226. Retrieved from http://www.trans-kom.eu/bd09nr02/ transkom_09_02_03_Tarquini_Databases.20161220.pdf.

Wang, D. (2017). Fansubbing in China - with reference to the fansubbing group YYeTs. The Journal of Specialised Translation. 28, 165-190. Retrieved from http://www.jostrans.org/issue28/art_wang.pdf

Wu,Y., Schuster, M., Chen, Z., Le, Q. V., \& Norouzi, M. (2016) Google's neural machine translation system: bridging the gap between human and machine translation. 8 Oct 2016. Retrieved from https://arxiv.org/abs/1609.08144v2

Xiangdong, Li. (2015). Putting interpreting strategies in their place: Justifications for teaching strategies in interpreter training. Babel. 61 (2), 170-192.

Zabalbeascoa, P. (2008) The nature of the audiovisual text and its parameters. The Didactics of Audiovisual Translation. John Benjamins Publishing Company, 21-37.

ЛЕКСИКОГРАФІЧНЕ ДЖЕРЕЛО

СУМ - Словник української мови: в 11-ти томах. Взято з http://sum.in.ua .

\section{REFERENCES}

Kravets, L. S. i Tatsenko H. V. (2012). Sotsiokulturni aspekty perekladu serialiv z anliyskoi movy na ukrainsku. Filologichni traktaty. 4 (3), 45-49. 
Melnyk, A. P. (2012). Ukrainsky koloryt u perekladakh suchasnykh animatsiynykh filmiv. Movni $i$ kontseptualny kartyny svitu. 42 (1), 103-113.

Sofiyenko, I. V. (2014). Stanovlennia kinoperekladu v Ukraini. Movni i kontseptualni kartyny svitu. 50 (2), 401-405. Vziato z http://nbuv.gov.ua/UJRN/Mikks_2014_50\%282\%29_59 .

Slyshkin, G. G. i Yefremova, M. A. (2004). Kinotekst (opyt lingvokulturovedcheskogo analiza). Moskva: Vodoley Publishers.

Artiukh, A. O. (2015). Classification of translators' mistakes in the movies for the Ukrainian audience. Visnyk Natsionalnoho tekhnichnoho universytetu Ukrainy "Kyivsky politekhnichnyi instytut". Seria: Filologia. Pedagogika. 5, 9-15. Vziato z http://nbuv.gov.ua/UJRN/vntufil_2015_5_4 .

Ayonghe, L. S. \& Ategha, A. (2017). The Power of film translation: Cameroon film industry and television documentaries: dubbing or subtitling? Translation Journal. January Issue. Retrieved from http://translationjournal.net/January-2017/the-power-of-film-translation-cameroon-film-industryand-television-documentaries-dubbing-or-subtitling.html .

Bartolomé, A. I. H. \& Carbera, G. M. (2005). New trends in audiovisual translation: the latest modes. Miscélanea : A Journal of English and American studies. 31, 89-104.

Chaume, F. (2013). The turn of audiovisual translation: new audiences and new technologies. Translation spaces. 2 (1), 105-123.

Chugu, S. \& Gladio, S. (2015). Modality of the literary text: Translation challenges. Наукові записки Наиіонального університету "Острозька академія". Серія "Філологічна". 59, 6-8.

Cintas, J. D. \& Sánchez, P. M. (2006). Fansubs: Audiovisual translation in an amateur environment. The Journal of Specialized translation. 06, 37-52. Retrieved from http://www.jostrans.org/issue06/ art_diaz_munoz.php .

Cintas, J. D. (2008) Introduction. The Didactics of Audiovisual Translation. John Benjamins Publishing Company, (pp. 1-18).

Gambier, Y. (2016). Rapid and radical changes in translation and translation studies. International Journal of Communication. 10, 887-906.

Tarquini, G. (2016). The deployment of audiovisual databases in foreign language learning: usability features and didactic affordances. Verstehen durch Hören und Lesen. Teil II: Perspektiven interlingualer Untertitelung 9:2, 208-226. Retrieved from http://www.trans-kom.eu/bd09nr02/ transkom_09_02_03_Tarquini_Databases.20161220.pdf

Wang, D. (2017). Fansubbing in China - with reference to the fansubbing group YYeTs. The Journal of Specialised Translation. 28, 165-190. Retrieved from http://www.jostrans.org/issue28/ art_wang.pdf.

Wu,Y., Schuster, M., Chen, Z., Le, Q. V. \& Norouzi, M. (2016) Google's neural machine translation system: bridging the gap between human and machine translation. 8 Oct 2016. Retrieved from https://arxiv.org/abs/1609.08144v2

Xiangdong, Li. (2015). Putting interpreting strategies in their place: Justifications for teaching strategies in interpreter training. Babel. 61 (2), 170-192.

Zabalbeascoa, P. (2008) The nature of the audiovisual text and its parameters. The Didactics of Audiovisual Translation. John Benjamins Publishing Company, 21-37.

SUM - Slovnyk Ukrainskoi movy v 11-ty tomakh. Vziato z http://sum.in.ua 